Received : 18 M aret 2020 Revised: 10 M ei 2020 Accepted:22 Juni 2020 Published : 31 Juli 2020

\title{
PERAN HUMAN CAPITAL DALAM MENINGKATKAN KINERJ A PERUSAHAAN PADA LEMBAGA PENGEMBANGAN PERBANKAN INDONESIA (LPPI)
}

\author{
A ASRORUDIN \\ Akuntansi S1, Fakultas Ekonomi, Universitas Pamulang \\ *Email: asrorudinahmad@gmail.com
}

\begin{abstract}
This study examines the effect of Individual Capability \& Motivation, Leadership, The Organizational Climate, and Workgroup Effectiveness on Non-Financial Performance of Companies in the Indonesian Banking Development Institute (LPPI). The research method used is quantitative methods. Samples in the study were 90 respondents. Data collection techniques using a questionnaire. The analysis technique used is the validity test, reliability test, regression analysis. The results showed that partially the Individual Capability \& Motivation variable, the Leadership variable did not have a significant effect on the Company's NonFinancial Performance at the Indonesian Banking Development Institute (LPPI). Whereas The Organizational Climate and Workgroup Effectiveness have a significant effect on the Company's Non-Financial Performance at the Indonesian Banking Development Institute (LPPI). Simultaneously, Individual Capability \& Motivation, Leadership, The Organizational Climate, and Workgroup Effectiveness have a significant effect on the Company's Non-Financial Performance at the Indonesian Banking Development Institute (LPPI) with a positive coefficient direction.
\end{abstract}

Keywords: Individual Capability \& Motivation, Leadership, The Organizational Climate, Non-Financial Performance. 


\section{PENDAHULUAN}

Industri perbankan saat ini sudah memasuki era baru, di mana sejak tahun 2017, era banking 4.0 diperkenalkan dengan kondisi embedded, perbankan bisa dilakukan di mana-mana disampaikan secara real time melalui keunggulan teknologi dan perkembangan teknologi juga berpengaruh pada pasar modal (wulandari, 2020). Selain didominasi oleh aktivitas real time, juga pengalaman kontekstual dan keterlibatan tanpa sentuhan, serta serangkaian aktivitas lain yang berbasis AI (artificial intelligence) yang cerdas. Sebagian besar lagi melalui saluran omni digital, tanpa saluran distribusi fisik (Nurdin, 2019b). Bank dan Industri Keuangan Non Bank (IKNB) seperti pegadaian, asuransi, perusahaan pembiayaan (multifinance) perlu mempertahankan kinerja untuk mampu bersaing dengan perusahaan fintech dan peningkatan kompetensi sumber daya manusia merupakan salah satu upaya yang dapat dilakukan untuk mempertahankan kinerja tersebut. Ada banyak dukungan untuk keyakinan bahwa program pengembangan karyawan memberikan kontribusi positif untuk kinerja organisasi (Jacobs, 2003), dan berdasarkan riset yang dilakukan oleh McDonald dan Smith (1995) dalam Jacobs (2003) dikutip dari (Nurdin, 2019a) bahwasanya perusahaan jasa keuangan terbuka di Amerika, menunjukkan perusahaan tanpa program manajemen kinerja, dan tanpa pengembangan karyawan, cenderung berkinerja relatif rendah terhadap rata-rata industri keuangan, sedangkan perusahaan dengan praktik manajemen kinerja dan pengembangan karyawan cenderung berprestasi di atas rata-rata industri.

Lembaga Pengembangan Perbankan Indonesia (LPPI), merupakan salah satu lembaga perusahaan swasta di Indonesia dalam kegiatannya memberikan dukungan layanan pendidikan pelatihan, penelitian, pengembangan dan konsultasi bidang perbankan ataupun jasa keuangan dengan tujuan peningkatan kualitas sumber daya manusia perbankan maupun jasa keuangan melalui pengembangan pengetahuan, keterampilan, dan sikap (knowledge, skill, attitude), serta sebagai center for leadership and ethics untuk industri perbankan dan jasa keuangan di Indonesia (LPPI, 2020). Fenomena selama ini, penilaian terhadap kinerja perusahaan secara internal pada Lembaga Pengembangan Perbankan Indonesia (LPPI) lebih banyak menggunakan sumber daya yang bersifat fisik (tangible asset) sehingga produktifitas dalam kinerja karyawan itu sendiri tidak tercapai. Penilaian kinerja perusahaan berbasis human capital merupakan hal menarik perlu dikembangkan oleh perusahaan. Human capital merupakan salah satu komponen utama dari Intellectual Capital (intangible asset) yang dimiliki perusahaan. Mayo (2000:115) berpendapat, mengukur kinerja perusahaan dari perspektif keuangan sangatlah akurat, tetapi sebenarnya, dasar penggerak nilai dari keuangan tersebut adalah sumber daya manusia (human capital) dengan segala pengetahuan, ide, dan inovasi yang dimilikinya. Selain itu, human capital juga merupakan inti dari suatu perusahaan (Endri, 2010). Menurut Mayo (2000:120) dalam (Endri, 2010), sumber daya manusia atau human capital memiliki lima komponen yaitu individual capability, individual motivation, leadership, the organizational climate, dan workgroup effectiveness. Setiap komponen memiliki peranan yang berbeda dalam menciptakan human capital perusahaan yang akan

* Corresponding author's e-mail: asrorudinahmad@gmail.com

http://openjournal.unpam.ac.id/index.php/JIA 
menentukan nilai sebuah perusahaan. Oleh karena itu, mengingat peran SDM yang begitu besar dalam perusahaan, maka, manajemen perusahaan harus lebih proaktif menjadikan SDM-nya sebagai human capital yang perlu diberi perhatian dan pengembangan secara terus menerus sesuai dengan kedinamisan lingkungan bisnis. Berdasarkan uraian tersebut di atas, maka penelitian tertarik meneliti fenomena Peran Human Capital dalam Meningkatkan Kinerja Perusahaan pada Lembaga Pengembangan Perbankan Indonesia (LPPI). Tujuan penelitian untuk mengetahui seberapa besar pengaruh Human capital terhadap Kinerja Non- Financial Perusahaan.

\section{LANDASAN TEORI}

\section{Labour process theory}

Labour process theory atau teori proses tenaga kerja dinyatakan bahwa proses tenaga kerja terjadi ketika kinerja (surplus) yang efektif diperoleh dari pengukuran sebagai bentuk pengendalian, implementasi ilmu manajemen dari pihak manajemen, penggunaan tekhnologi, dan kontribusi tenaga kerja yang mana pelaksanaan pekerjaan tersebut diselesaikan secara efesien disertai pemberian imbalan tenaga kerja (Sridadi, 2016).

\section{Agency theory}

Teori Agensi menandaskan bahwa principal, dalam hal ini pemilik perusahaan atau manajer, melakukan kegiatan monitoring dan pengendalian terhadap para staf, dalam hal ini bertindak sebagai agen, untuk memastikan para agen memenuhi tujuan-tujuan yang telah ditetapkan oleh para principalnya (Sridadi, 2016).

\section{Exchange theory}

Exchange theory atau teori pertukaran merupakan terjadinya interaksi antara pekerja dan manajemen dimana terjadinya pertukaran diantara keduanya. Pertukaran tersebut antara lain: Imbalan (rewards), biaya (cost), keluaran (outcomes), dan tingkat perbandingan (level of comparations) (Sridadi, 2016).

\section{Kinerja Perusahaan}

Kinerja perusahaan adalah suatu tampilan keadaan secara utuh atas perusahaan selama periode waktu tertentu, dan merupakan hasil atau prestasi yang dipengaruhi oleh kegiatan-kegiatan operasional di dalam perusahaan dalam memanfaatkan sumber daya yang dimiliki oleh perusahaan tersebut. Menurut Rivai dan Basri (2004:16) dalam (Nugraha, Susilo, \& Aini, 2018) "pengertian performance atau kinerja adalah hasil kerja yang dapat dicapai oleh seseorang atau kelompok orang dalam satu perusahaan sesuai dengan wewenang dan tangung jawab masing-masing dalam upaya pencapaian tujuan perusahaan secara legal dan tidak melanggar hukum dan tidak bertentangan dengan etika dan moral. Hasil dari kinerja perusahaan yang dihasilkan oleh suatu perusahaan akan mengacu pada standar yang telah ditetapkan oleh suatu perusahaan. Pengukuran aktivitas kinerja suatu perusahaan dirancang untuk menaksir bagaimana kinerja aktivitas dan hasil akhir 
yang telah dicapai oleh perusahaan tersebut. Setiap perusahaan memiliki performa yang berpengaruh terhadap financial capital dan non financial capital.

\section{Human Capital}

Menurut Malhotra dan Bontis dalam Ongkorahardjo et al. (2008:12-13) (Aprilia, 2016): Human Capital merupakan kombinasi dari pengetahuan, keterampilan, inovasi, dan kemampuan seseorang untuk menjalankan tugasnya sehingga dapat menciptakan suatu nilai untuk mencapai tujuan. Pembentukan nilai tambah dikontribusikan oleh human capital dalam menjalankan tugas dan pekerjaannya akan memberikan sustainable revenue di masa yang akan datang bagi suatu organisasi. Mayo (2000:120) dalam (Endri, 2010), sumber daya manusia atau human capital memiliki lima komponen yaitu individual capability, individual motivation, leadership, the organizational climate, dan workgroup effectiveness.

\section{M TODOLOGI P N LITIAN}

Penelitian ini merupakan penelitian penjelasan (explanatory research) dengan pendekatan kuantitatif. Penelitian dilakukan pada Lembaga Pengembangan Perbankan Indonesia (LPPI). Didapat sampel jenuh 90 orang responden dengan pengumpulan data menggunakan kuesioner, dengan skala likert digunakan lima alternatif jawaban dengan kriteria sebagai berikut: $1=$ Sangat Tidak Setuju; $2=$ Tidak Setuju; 3 = Netral; 4 = Setuju; 5 = Sangat Setuju.

Pengujian validitas dilakukan menggunakan program SPSS for Windows versi 16. Dalam penelitian ini pengujian validitas dan reabilitas dilakukan terhadap 30 responden sebagi langkah awal penelitian. Adapun responden yang diambil pada perusahaan yang berbeda dengan jenis industri yang sama. Selanjutnya dilakukan analisa nilai $r$ yang diperoleh dibandingkan dengan nilai $r$ tabel sesuai dengan baris $\mathrm{n}$ dan taraf signifikasi $(\alpha=5 \%)$. Pengujian validitas, kuesioner dikatakan valid apabila $r$ hitung $>r$ tabel (Imam Ghozali, 2006).

Analisis statistik yang digunakan dalam penelitian ini yaitu regresi linier berganda. Analisis untuk mengetahui besarnya pengaruh variabel-variabel bebas (independent) yaitu Individual capability \& motivation (X1), leadership (X2), the organizational climate (X3) dan Workgroup effectiveness (X4) terhadap variabel terikat (dependent) yaitu kinerja perusahaan (Y).

Adapun perhitungan regresi nantinya dalam penelitian ini besarnya pengaruh variabel independent (Individual Capability \& Motivation, Leadersip, The Organizational Climate, dan Workgroup Effectiveness) dengan variabel dependent (kinerja perusahaan) secara bersama-sama dapat dianalisis melalui hasil pengujian dilihat dari uji t yang mana apabila $t$ hi- tung $>\mathrm{t}$ tabel dan signifikansi t hitung $<\alpha$ , maka Ho ditolak dan Ha diterima. Dan apabila t hitung < t tabel dan signifikansi $t$ hitung $>\alpha$, maka Ho diterima dan Ha ditolak, dengan taraf signifikan 0,05. Untuk uji $\mathrm{F}$, jika $\mathrm{F}$ hitung < $\mathrm{F}$ tabel (k, n-k-1) dan signifikansi $\mathrm{F}$ hitung > $\alpha$, maka: Ho diterima dan Ha ditolak, begitu juga berlaku sebaliknya (Margono, 2003: 194) dalam (Arianto, 2013). 
Jurnal Ilmiah Akuntansi Universitas Pamulang - Vol. 8, No. 2, Juli 2020 - Asrorudin

Operasional Variabel dan Indikator

Tabel 1. Variabel dan Indikator

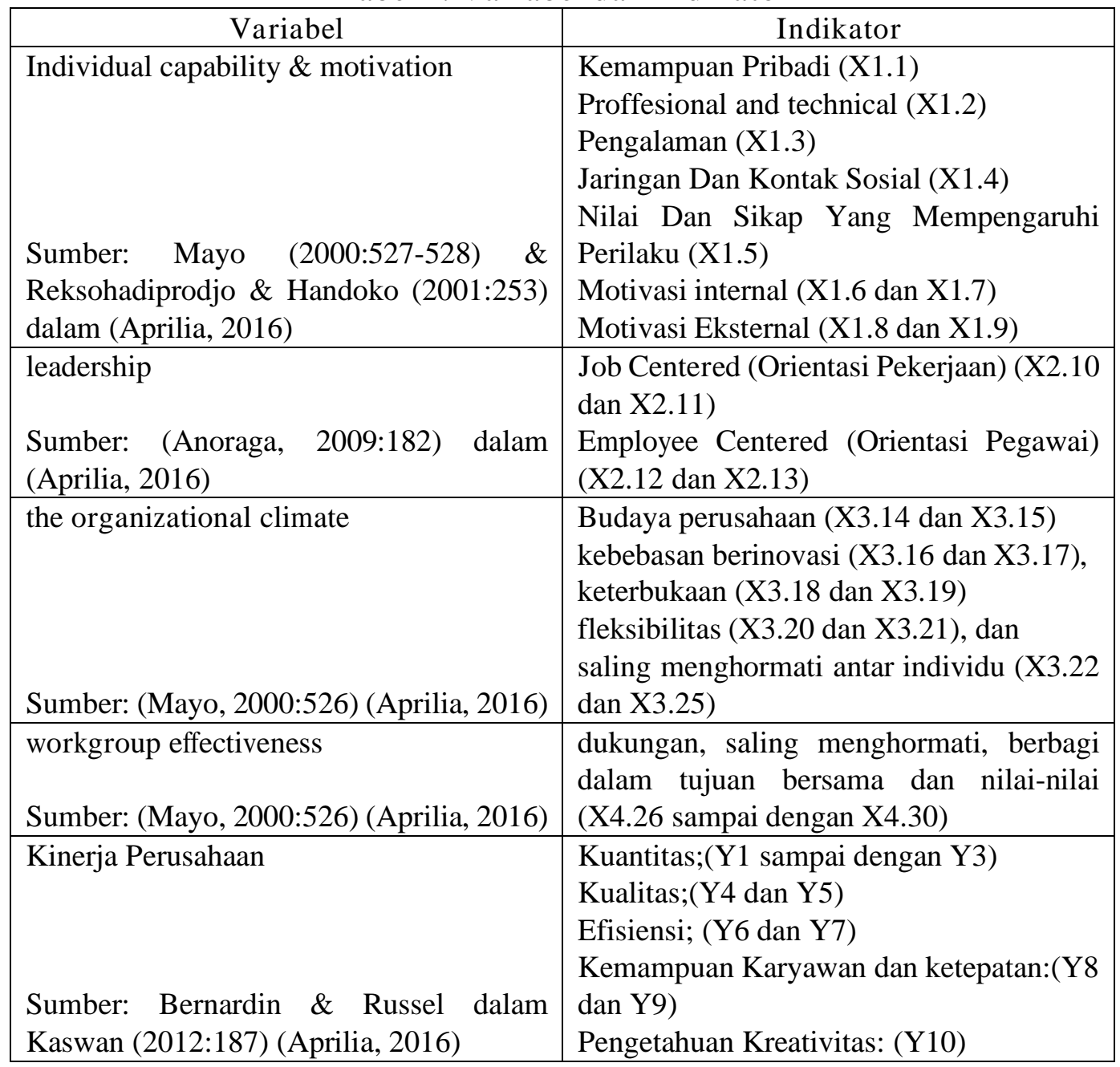

\section{HASIL PENELITIAN DAN PEMBAHASAN}

Hasil Penelitian

Tabel 2. Hasil Analisis Regresi

\begin{tabular}{|l|r|r|}
\hline \multicolumn{1}{|c|}{ Variabel } & Koefisien & \multicolumn{1}{c|}{ Signifikan } \\
\hline Constant & -2.784 & .491 \\
Individual capability \& motivation & .176 & .156 \\
Leadership & .284 & .193 \\
The organizational climate & .247 & .012 \\
Workgroup effectiveness & .910 & .000 \\
$\mathrm{~F}$ (Sig.) & 33.134 & $(0.000)$ \\
\hline $\mathrm{R}$ & 0.781 \\
$\mathrm{Adjusted} \mathrm{R}^{2}$ & 0.591 & \\
$\mathrm{~N}$ & 90 \\
\hline
\end{tabular}

Sumber: Data Olah 2020 
Berdasarkan hasil perhitungan estimasi regresi diperoleh nilai koefisien determinasi yang disesuaikan (adjusted $R^{2}$ ) adalah 0,591 artinya 59,1\% variasi dari semua variabel bebas (Individual Capability \& Motivation, Leadersip, The Organizational Climate, dan Workgroup Effectiveness) dapat menerangkan varia bel terikat (Kinerja Perusahaan), sedangkan sisanya sebesar 40,9\% diterangkan oleh variabel lain yang tidak diajukan dalam penelitian ini.

Koefisien positif dan nilai signifikansi Individual capability \& motivation terhadap Kinerja Perusahaan pada Lembaga Pengembangan Perbankan Indonesia (LPPI) menunjukkan tidak adanya pengaruh signifikan dilihat dari besaran angka 0,156 lebih besar dari 0,05, sehingga disimpulkan Individual capability \& motivation tidak mempunyai pengaruh terhadap Kinerja Perusahaan. Begitu pula dengan variable leadership juga tidak mempunyai pengaruh secara signifikan terhadap kinerja perusahaan dilihat dari angka 0,193 lebih besar dari 0,05, sehingga dapat disimpulkan kedua variable tersebut yaitu variable Individual capability \& motivation dan variable leadership tidak mempunyai pengaruh secara signifikan terhadap Kinerja Perusahaan.

Untuk nilai signifikansi variable yang mempunyai pengaruh terhadap kinerja perusahaan pada Lembaga Pengembangan Perbankan Indonesia (LPPI) yaitu variable The organizational climate sebesar 0,012 dan variable Workgroup effectiveness dengan nilai sebesar 0.000 masing-masing variable tersebut lebih kecil dari 0,05 sehingga disimpulkan The organizational climate dan Workgroup effectiveness mempunyai pengaruh positif paling besar terhadap Kinerja Perusahaan pada Lembaga Pengembangan Perbankan Indonesia (LPPI).

Sedangkan uji F (F-test) dari hasil perhitungan output, nilai F hitung sebesar 33,134 dengan nilai signifikan 0,000 lebih kecil dari 0,05 sehingga dapat disimpulkan Individual Capability \& Motivation, Leadersip, The Organizational Climate, dan Workgroup Effectiveness secara bersama-sama berpengaruh positif terhadap Kinerja Perusahaan pada Lembaga Pengembangan Perbankan Indonesia (LPPI).

Pembahasan

1) Pengaruh Individual Capability \& Motivation terhadap Kinerja NonFinancial Perusahaan.

Hasil pengujian regresi menunjukan nilai koefisien Individual capability \& motivation sebesar 0,176 dengan signifikansi sebesar 0,156, dikarenakan nilai signifikansi nya $>0.05$, maka hipotesis pertama dinyatakan besarnya pengaruh individual capability \& Motivation terhadap kinerja non financial perusahaan ditolak dalam artian bahwasannya Individual capability \& motivation tidak mempunyai pengaruh terhadap Kinerja Perusahaan.

Hasil penelitian ini mengindikasikan tidak adanya pengaruh tersebut dapat dilihat dari aspek sumber daya manusia yang ada tidak dijadikan sebagai salah satu sumber daya yang berwujud seperti mesin, uang, material, data dan informasi sebagai penggerak sumber daya lainnya. Dalam kaitannya dengan tenaga sumberdaya dalam kegiatannya memberikan dukungan layanan pendidikan pelatihan, penelitian, pengembangan dan konsultasi bidang perbankan ataupun jasa keuangan pada Lembaga Pengembangan Perbankan 
Indonesia (LPPI) harus memiliki pengetahuan khusus yang terkait dengan hubungan bisnis yang dimiliki dengan ditentukan oleh attitude (bakat), tingkat kemampuan \& keterampilan (skill level), motivasi, persepsi terhadap peran (role perseption), tipe produk, dan tipe konsumen yang dihadapi di mana kemampuan ini dapat diketahui dari luasnya pengetahuan yang dimiliki.

Secara Labour process theory (Hoque, Kessler, Pepper, Richardson, \& Walker, 2013; Michael Armstrong, 2006) di mana kemampuan Individu (Individual Capability) suatu prioritas sangat penting meliputi pengetahuan, keterampilan, pengalaman, jaringan, kemampuan untuk mencapai hasil, potensi untuk berkembang dan apa yang mereka bawa ke dalam pekerjaan dari kehidupan mereka selalu memberikan sustainable revenue bagi organisasi.

2) Pengaruh Leadership terhadap Kinerja Non- Financial Per usahaan

Hipotesis Kedua menunjukan nilai koefisien Leadership sebesar 0,284 dengan signifikansi sebesar 0,193, dikarenakan nilai signifikansinya $>0.05$, maka hipotesis kedua yang menyatakan besarnya pengaruh Leadership terhadap kinerja non financial perusahaan dapat ditolak dalam arti bahwasannya Leadership tidak mempunyai pengaruh terhadap Kinerja Perusahaan.

Hasil penelitian ini mengindikasikan tidak adanya pengaruh tersebut dikarenakan kejelasan visi tentang manajemen puncak dan kemampuan mereka untuk berkomunikasi dan berperilaku belum berjalan dengan cara yang konsisten hal tersebut dapat dilihat dari kemampuan mempengaruhi aktivitas orang lain melalui komunikasi, baik individual maupun kelompok, ke arah pencapaian tujuan. Dalam perusahaan, kepemimpinan melibatkan kemampuan mempengaruhi karyawan untuk mencapai misi perusahaan. Pemimpin mempengaruhi individu maupun kelompok melalui proses komunikasi. Pemimpin dapat muncul karena memang dilahirkan untuk menjadi pemimpin, atau muncul karena persiapan dan didikan serta bisa juga gabungan dari keduanya, bila sejak lahir sudah mempunyai bakat kepemimpinan dan selanjutnya bakat ini dikembangkan melalui pendidikan dan pengalaman serta disesuaikan dengan tuntutan lingkungan.

Secara teori menurut Boone dan Kurtz dalam Anoraga (2009:195)(Aprilia, 2016) setiap kepemimpinan selalu menggunakan power atau kekuasaan yang diperoleh dari beberapa sumber yaitu: 1) Reward, di mana kekuasaan yang diperoleh melalui reward dilakukan oleh pemimpin dengan cara memenuhi kebutuhan bawahan seperti pemberian bonus dan liburan, 2) Coercive, di mana kekuasaan ini diperoleh melalui ancaman dan hukum terhadap bawahan. 3) Expert, merupakan kekuasaan dalam bentuk lain yaitu keahlian di mana seseorang dapat mempengaruhi orang lain melalui keterampilan dan pengetahuan yang dimilikinya. 4) Referent, merupakan kekuasaan dalam bentuk panutan atau idola. 5) Legitimate, yaitu kekuasaan yang diperoleh karena kewenangannya yang sah.

3) Pengaruh The Organizational Climate terhadap Kinerja Non-Financial Perusahaan

Hipotesis Ketiga menunjukan nilai koefisien Organizational Climate sebesar 0,247 dengan signifikansi sebesar 0,012, dikarenakan nilai signifikansi 
nya $<0.05$, maka hipotesis ketiga yang menyatakan besarnya pengaruh Organizational Climate terhadap kinerja non financial perusahaan dapat diterima dalam arti bahwasanya Organizational Climate mempunyai pengaruh terhadap Kinerja Perusahaan. Adanya pengaruh tersebut dibuktikan dengan Suasana Organisasi (The Organizational Climate), meliputi budaya perusahaan, kebebasan berinovasi, keterbukaan, fleksibilitas, dan saling menghormati antar individu. Menurut Mayo (2000:530) dalam (Aprilia, 2016), budaya organisasi adalah faktor yang sangat penting dalam menciptakan human capital, yaitu: 1. Melakukan penilaian atas kinerja baik dalam tim maupun perseorangan. 2. Melakukan penilaian terhadap karyawan dalam mengahadapi masalah melalui proses pembelajaran dan perbaikan diri. 3 . Menciptakan inovasi-inovasi baru dan kreativitas individu yang bernilai yang tujuannya untuk memperbaiki kondisi perusahaan. 4. Adanya dukungan dari perusahaan berupa adanya sarana dan prasarana yang lengkap bagi para karyawan dalam bekerja dan melaksanakan tugasnya. 5. Adanya transfer knowledge dari para senior kepada junior, saling berbagi pengalaman dalam bekerja.

4) Pengaruh Workgroup Effectiveness terhadap Kinerja Non Financial Perusahaan

Hipotesis Ke-empat menunjukan nilai koefisien Workgroup Effectiveness sebesar 0,247 dengan signifikansi sebesar 0,012, dikarenakan nilai signifikansi nya $<0.05$, maka hipotesis ke-empat yang menyatakan besarnya pengaruh Workgroup Effectiveness terhadap kinerja non financial perusahaan dapat diterima dalam arti bahwasannya Workgroup Effectiveness mempunyai pengaruh terhadap Kinerja Perusahaan. Adanya pengaruh tersebut dibuktikan dengan Efektifitas Kelompok Kerja (Workgroup Effectiveness), meliputi dukungan, saling menghormati, berbagi dalam tujuan bersama dan nilai-nilai. Kelompok kerja lebih dikenal dengan tim kerja. Dalam tim kerja akan terjalin hubungan yang baik antar angggota tim, tetapi juga mungkin akan muncul konflik di dalam tim kerja itu sendiri (Mayo, 2000:530) dalam (Aprilia, 2016)

\section{KESIMPULAN}

Berdasarkan hasil penelitian dan pembahasan mengenai Individual Capability \& Motivation, Leadership, The Organizational Climate, Workgroup Effectiveness terhadap Kinerja Non- Financial Perusahaan dapat ditarik kesimpulan sebagai berikut:

1. Individual capability \& motivation tidak mempunyai pengaruh terhadap Kinerja Perusahaan Non- Financial.

2. Leadership tidak mempunyai pengaruh terhadap Kinerja Perusahaan NonFinancial.

3. Organizational Climate mempunyai pengaruh terhadap Kinerja Perusahaan Non- Financial.

4. Workgroup Effectiveness mempunyai pengaruh terhadap Kinerja Perusahaan Non- Financial. 
Jurnal Ilmiah Akuntansi Universitas Pamulang - Vol. 8, No. 2, Juli 2020 - Asrorudin

5. Individual Capability \& Motivation, Leadersip, The Organizational Climate, dan Workgroup Effectiveness secara bersama-sama berpengaruh terhadap Kinerja Perusahaan Non- Financial.

\section{DAFTAR PUSTAKA}

Aprilia, H. D. (2016). Pengembangan Human Capital Dalam Meningkatkan Kinerja Tenaga Pemasar Produk Asuransi Jiwa. Thesis Universitas Bandar Lampung, 1-74. Retrieved from http://digilib.unila.ac.id/21921/3/TESIS TANPA BAB PEMBAHASAN.pdf

Arianto, D. A. N. (2013). Pengaruh Kedisiplinan, Lingkungan Kerja Dan Budaya Kerja Terhadap Kinerja Tenaga Pengajar. Jurnal Economia, 9(2), 191-200. https://doi.org/10.21831/economia.v9i2.1809

Endri. (2010). Peran Human Capital Dalam Meningkatkan Kinerja Perusahaan: Suatu Tinjauan Teoritis Dan Empiris. ILMU Dan BUDAYA, 6(2), 2342-2356.

Hoque, K., Kessler, I., Pepper, A., Richardson, R., \& Walker, L. (2013). Human resource management. London: University of London.

Imam Ghozali. (2006). Aplikasi Analisis Mutivariat dengan Program SPSS (Cetakan IV). Semarang: Undip.

LPPI. (2020). LPPI. Retrieved February 26, 2020, from http://lppi.or.id/pages/about/

Michael Armstrong. (2006). HUMAN MANAGEMENT RESOURCE PRACTICE (10TH EDITI). London and Philadelphia: Cambridge University Press.

Nugraha, P. C., Susilo, H., \& Aini, E. K. (2018). PENGARUH HUMAN CAPITAL TERHADAP KINERJA PERUSAHAAN (Studi pada Perusahaan Advertising dan Periklanan Malang yang Terdaftar pada Asosiasi Advertising dan Periklanan Malang). Administrasi Bisnis (JAB), 57(2), 180-189.

Nurdin, M. A. (2019a). Lembaga Keuangan telah memiliki training center sendiri, berubah dan bertransformasi menjadi sebuah Corporate University ( Corpu ). Majalah Stabilitas, LPPI No.:

Nurdin, M. A. (2019b). Perubahan budaya organisasi di era digital. Majalah Stabilitas, (No. 154/April-Mei 2019 Th. XIV), 1-2.

Sridadi, A. R. (2016). Perjanjian Kerja Bersama Antara Pengurus dan Serikat Pekerja dalam Perspektif Manajemen Sumber Daya Manusia. Empat Dua Media (cv. Cita Intrans Selaras).

Wulandari, R., \& Prasetya, E. R. (2020). Pengaruh Penerapan Teknologi Informasi Dan Profesionalisme Terhadap Kinerja Auditor. EkoPreneur, 1(2), 202-217. 